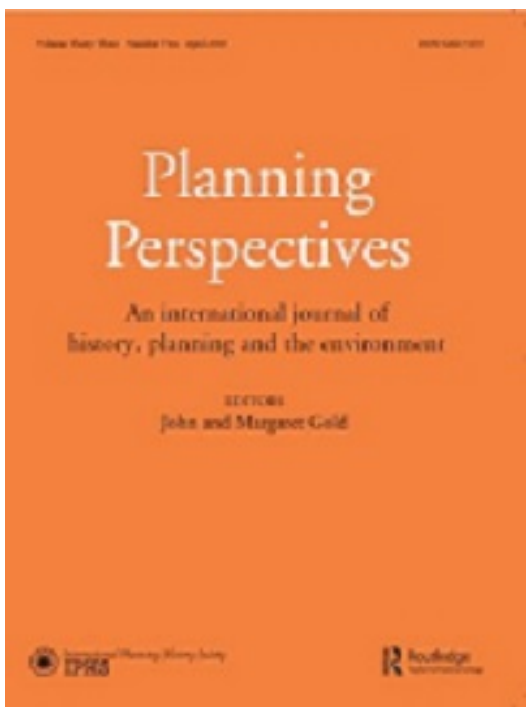

\title{
A city made of rooms. Revisiting the interactions between urban planning and building typology in Mario Ridolfi's projects for Terni
}

\begin{tabular}{|r|l|}
\hline Journal: & Planning Perspectives \\
\hline Manuscript ID & RPPE-2018-0109.R1 \\
\hline Manuscript Type: & Original Article \\
\hline Keywords: & Mario Ridolfi, urban planning, Terni, public space, palazzina \\
\hline \multicolumn{2}{|l}{} \\
\end{tabular}

\section{SCHOLARONE ${ }^{\text {TM }}$ \\ Manuscripts}


Mario Ridolfi's lifelong work in the area around the Corso del Popolo in the city of Terni has merited special attention among researchers because of its sensitiveness towards the historical surroundings, its ability to integrate townplanning and architecture and its capacity to transform the city's skin and structure. The aim of the paper is to shed light on the origins, design strategies and translation into architecture that informed the approval of the Variante al Piano di Ricostruzione Corso del Popolo, piazza del Popolo e zone adiacenti in 1959. A comparative analysis of mainly unpublished, original sketches dating back to 1932 helps to understand the planning precedents that ultimately led to the decision to open the Corso del Popolo (1984 to 1932), the variations of the specific layout of this urban project from 1932 to its approval in 1959 and the unique application of planning strategies into Ridolfi's buildings for central Terni. The study reveals the persistence of previous planning ideas that were not proposed but accepted by Ridolfi, the depiction of the 'squared street' as a new paradigm of open space, and the intrinsic paradoxes that informed the difficult embedding of the palazzina typology into the fragile urban fabric of the old city centre. 


\title{
A city made of rooms. Revisiting the interactions between urban planning and building typology in Mario Ridolfi's projects for Terni
}

\author{
Mario Ridolfi's lifelong work in the area around the Corso del Popolo in \\ the city of Terni has merited special attention among researchers because \\ of its sensitiveness towards the historical surroundings, its ability to \\ integrate town-planning and architecture and its capacity to transform the \\ city's skin and structure. The aim of the paper is to shed light on the \\ origins, design strategies and translation into architecture that informed the \\ approval of the Variante al Piano di Ricostruzione Corso del Popolo, \\ piazza del Popolo e zone adiacenti in 1959. A comparative analysis of \\ mainly unpublished, original sketches dating back to 1932 helps to \\ understand the planning precedents that ultimately led to the decision to \\ open the Corso del Popolo (1984 to 1932), the variations of the specific \\ layout of this urban project from 1932 to its approval in 1959 and the \\ unique application of planning strategies into Ridolfi's buildings for \\ central Terni. The study reveals the persistence of previous planning ideas \\ that were not proposed but accepted by Ridolfi, the depiction of the \\ 'squared street' as a new paradigm of open space, and the intrinsic \\ paradoxes that informed the difficult embedding of the palazzina typology \\ into the fragile urban fabric of the old city centre.
}

Keywords: Mario Ridolfi; urban planning; Terni; public space; palazzina

\section{Introduction}

From the late 1940s, the architect Mario Ridolfi, often in collaboration with Wolfgang Frankl, left an indelible trace on the city of Terni through his urban plans for the reconstruction and extension of the city and the construction of a considerable number of buildings. The latter were instantly recognizable from their language and were distributed around the city, from the historic centre to the new expansion areas. These works were imitated frequently by local professionals. As Paolo Portoghesi stated: 
'There are at least a thousand buildings in Terni constructed in the last thirty years that consciously or unconsciously have been erected using the language that the master [Ridolfi] refined from the 1950s. These buildings vary greatly from each other in their quality and formal features, but they all belong to the same family, with constant and easily recognizable physiognomic characteristics'. ${ }^{1}$ The cumulative outcome of this process is admittedly unique. It would be difficult to find another example of a post-war European city that has been so clearly marked by the continuous work of a single architect over several decades.

The example of Terni has been the focus of numerous perspectives and approaches in Italian and Spanish research. Notable are a number of urban history reviews of the sequence of plans that culminated in the Piano Regolatore Generale of Terni, ${ }^{2}$ the well-illustrated compendia of works and papers published in specialized journals like Controspazio 1974 (1 and 3) and 1979 (5 and 6) and other complete monographs on the issue. ${ }^{3}$ In-depth studies have been undertaken on many of Mario

\footnotetext{
${ }^{1}$ Portoghesi, 'Una Città d'autore', 17.

${ }^{2}$ Coppa, 'Il Piano Regolatore Di Terni'; Coppa, 'Il Piano Regolatore Di Terni: Parte Seconda'; Fraticelli, 'Terni: Progetto e Città'; Pirro, Enrico Lattes: L'architetto Ritrovato; Tarquini, La Forma Della Città Industriale. Terni. Il Progetto Delle Parti.

${ }^{3}$ Brunetti, Mario Ridolfi; Sánchez and Recuenco, Mario Ridolfi (1904-1984). La Arquitectura de Ridolfi y Frankl; Bellini, Mario Ridolfi; Palmieri, Mario Ridolfi. Guida All'architettura; Nicolini, Mario Ridolfi: Architetto: 1904-2004.
} 
Ridolfi's projects and influences ${ }^{4}$ and there is an ambitious and interesting explanation of these architectural elements in Terni. ${ }^{5}$

This paper highlights the value of an outstanding group of projects that emerged in relation to the Variante al Piano di Ricostruzione Corso del Popolo, piazza del Popolo e zone adiacenti, a plan approved on $04 / 04 / 1959$ by a Decreto del Ministero dei LL. PP (no 260). The hypothesis is that through this plan, M. Ridolfi and W. Frank1 integrated town-planning considerations and architecture, with clear sensitiveness towards Terni's historical district. The Corso del Popolo plan could be considered the largest modernization operation in the centre of Terni and a relevant scenario for testing delicate, innovative collective housing.

${ }^{4}$ Palmieri, Mario Ridolfi. Guida All'architettura; Polin, 'Mario Ridolfi, Volfango Frankl, Domenico Malagricci. Nuovo Palazzo per Uffici Del Comune Di Terni’; Cellini, ‘Su Mario Ridolfi. Geometria e Costruzione Della Pianta Centrale’; Cellini, D'Amato, and Palmieri, Mario Ridolfi: Manuale Delle Tecniche Tradizionali Del Costruire: Il Ciclo Delle Marmore; Cellini and D’Amato, Mario Ridolfi All'Academia Di San Luca; Feduchi, 'Memoria y Lugar: Una Reflexión Sobre La Actuación de Mario Ridolfi y Wolfgang Frankl En Torno Al Palacio Spada de Terni'; Soto, 'Forma y Lugar'; Moschini and Rattazzi, Mario Ridolfi. La Poetica Del Dettaglio; Cavallari, Ridolfi e Frankl: Progettare e Costruire. Il Nuovo Palazzo per Uffici Comunali a Terni.

${ }^{5}$ Prosperetti, ‘La Apertura Del Corso Del Popolo En Terni: Un ‘Sventramento’ de Mario Ridolfi'; Tarquini, Terni, Città d'autore: Guida Ad Un Percorso Ridolfiano; Tarquini, La Città Di Mario Ridolfi; Portoghesi, 'Una Città d'autore', 2005. 
Through the analysis of mainly unpublished working drawings on this area, this paper aims to complement the literature on the subject by shedding light on the design strategies that led to its recognizable urban layout of setbacks and vibrating alignment, porticoes and outstanding architectural elements. What were the origins, references and evolution of the design strategies used by Mario Ridolfi for the Corso del Popolo from his first entry to the Piano Regolatore competition in 1932 to the version that was approved in $1959 ?$

\section{Methodology and structure}

The arguments and conclusions presented in this paper are based on the interpretation of primary and secondary sources obtained from a systematic review of literature on the topic, consultation of the original manuscripts and graphic documentation available in the Accademia di San Luca archives, the redrawing and comparison of over thirty unpublished drawings in Luciano Marchetti's Archive (Terni), the recording of interviews with engineers and collaborators on these projects, a review of the documents provided by the Municipality of Terni and a field visit to the area. The primary documentation was arranged in chronological order and then subdivided into three areas of study: general urban planning, the design process for the Piano Particolareggiato del Corso del Popolo and the detailed scope of the architectural design in that area.

\section{Corso del Popolo and the foundation of modern Terni}

Mario Ridolfi's and Mario Fagiolo's fountain in Piazza Tacito, Terni, was inaugurated in 1932 and marked the starting point of Mario Ridolfi's continuous engagement with the new capital of the province until his death in 1984 . The fountain's water movement recalled the Marmore Falls that produced the energy for the steel plants opened in the 
mid-eighteenth century. Like other Italian steel producers such as Geneva or Taranto, the city of Terni gradually became a dual city tensioned by the specialized logics of the industrial areas and their deep influence on social demands and urban modernization. ${ }^{6}$ This could explain why, according to Aldo Tarquini, Terni's transformation in the mid twentieth century was associated with a deeply rooted industrial culture rather than the political context, such as the fascist regime in $1923 .{ }^{7}$ In the case of the invention and construction of the Corso del Popolo, these general considerations could be examined by comparing the sequence of unbuilt plans that preceded the final solution built by Mario Ridolfi's studio. Three key episodes in the history of the general form of Terni can be differentiated here:

\section{First episode: retracing Terni's city centre}

The first general ideas for the transformation of Terni's Roman fabric were introduced after the arrival of the railroad in the city between 1865 and $1869 .{ }^{8}$ This meant that a direct connection to the historical city centre was required through a new straight avenue: Corso Cornelio Tacito. This new north-south avenue cut through the city centre with a relatively moderate width $(16 \mathrm{~m})$, enabling good integration with the existing fabric. The street was combined with a transverse avenue (Viale Cesare Battisti/Benedetto Brin) that crossed at the cornerstone of the new main square (Piazza Cornelio Tacito), thus generating a new modern coordinate system.

\footnotetext{
${ }^{6}$ Portelli, Biografia Di Una Città. Storia e Racconto: Terni 1830-1985.

${ }^{7}$ Tarquini, La Forma Della Città Industriale. Terni. Il Progetto Delle Parti, 40.

${ }^{8}$ Coppa, 'Il Piano Regolatore Di Terni', 69-76.
} 
Gaetano Possenti's plan in 1884 (Figure 1(a)) can be interpreted from the perspective of the mid-nineteenth century tradition of urban extension grids and the renewal of old European cities. His project envisaged a new district between Terni's old core and the station by converging two grid geometries and preserving the existing Fonderia (foundry). A new industrial district was also located to the east of the city. In turn, the old city centre was meant to be drastically renewed by overlaying a new grid system (ca. 120x120 m) and new diagonal streets. The area that later became the Corso del Popolo (see the bold line) was part of a new grid that followed the direction of the former Roman cardus (the Via Roma). Therefore, it was a first attempt to include this less dense area into the general structure of Terni.

The plan created by the Commissione Edilizia in 1886, approved in 1887 (Figure 1(b)), was designed to fit the previous plan into the demands of industrial promoters. ${ }^{9}$ The new plan reshaped the district surrounding Cornelio Tacito's square and restructured links with the industrial area's infrastructure to the north and east. The plan also confirmed the hypothesis that the area east of Palazzo Spada, the future Corso del Popolo, ought to be considered a city expansion; a new urban grid.

After some minor planning interventions such as the plan led by Cassian Bon in 1911, the post-war plan designed by the engineer Giovanni di Vella and approved in 1919 focused more on the development of Terni's bourgeois districts (the Quartiere Battisti and Città Giardino). The plan also continued with the idea of a grid extension for the future area of Corso del Popolo and, more importantly, it pursued a major renovation in the Piazza Vittorio Emanuele, including the demolition of the Church of

\footnotetext{
9 Tarquini, La Forma Della Città Industriale. Terni. Il Progetto Delle Parti, 29.
} 
San Giovanni Decollato and the construction of the new Palazzo delle Poste (19181936) by the architect Cesare Bazzani.

After the nomination of Terni as capital of the province in 1927, the engineer Fabrizio Ramaccioni drew up a new plan in $1931^{10}$ (Figure 1(c)), which developed an ambitious yet extemporaneous image for the city's extension and modernization. The provisions for the inner city included widening some streets and the idea of a ring road avenue.

Although no major transformation were executed in this period, the plans established a way to shape the city by expanding it and addressing its implosion through successive overlapped coordinates: from the cardus-decumanus Roman scheme towards the Piazza Cornelio Tacito and, finally, with the Corso del Popolo as a strategic needle pointing to the heart of the city, establishing a new centre of gravity for development to the south.

\section{Second episode: a curved street or a straight sventramento?}

Terni's general urban form was under discussion again from 1932 onwards, due to the national competition for the new Piano Regolatore that was organized to determine the future development of the city and its renewal. ${ }^{11}$ The team lead by Mario Ridolfi together with Gaetano Minnucci, Alfio Susini, Mario Fagiolo and Frenguelli received the ex aequo award (Figure 2(a)). The winning project was by architects Saul Bravetti and Enrico Lattes and engineer Tullio Staderini (Figure 2(b)). It was approved on 4

\footnotetext{
${ }^{10}$ Cristofori, Terni e Bilbao. Città Europee Dell'acciaio; Pirro, Enrico Lattes: L'architetto Ritrovato, 217.

${ }^{11}$ Fuselli, 'Il Concorso Nazionale per Il Piano Regolatore Di Terni'.
} 
August 1934 and became a Decreto Lege on 14 July 1937.

Both proposals focused on the construction of a new street network for the city by strengthening the existing structure or adding new streets. While there was a clear coincidence in the opening of parallel streets to the Roman decumanus, the decision to replicate the cardus (Via Roma) was approached in several ways. Ridolfi's layout followed a combed-arch geometry to use the existing Roman bridge and turn the back courtyards of that district into a new urban space.

Conversely, Bravetti's more resolute proposal relied on a new bridge and drew a straight axis up to Terni's centre. While Ridolfi's version could be read as an ad-hoc response to the existing urban fabric and a variant to Terni's former main street, Bravetti clearly aimed to introduce a new dimension to the existing city: a way of turning the city upside down from its very centre, a new modern foundation for the city towards the south. Indeed, in much the same way as the inauguration of the station produced a new square between it and the old city centre, the coordinate system led by the new Corso Littorio (later the Corso del Popolo) signified a new modern centrality, an augmentation in the city's scale.

More broadly, Bravetti's new axis could be linked to the tradition of the opening of streets or sventramento that had been key to the transformation of European capitals since the sixteenth century: from the radical transformation of Rome in the Baroque period to the paradigmatic opening of streets like Regent Street in London (ca. 1811), Carrer Ferran in Barcelona (1823), Via Roma in Palermo (1885) or the radical transformation of the city of Paris by Haussmann (1852). More specifically, Bravetti's sventramento can be directly linked to the Roman experience that had fostered the opening of Corso Vittorio Emmanuele II in 1886, and promoted the Piano Regolatore Generale of Rome in 1883 and 1909. In the latter, another sventramento had been 
proposed between Piazza Venezia and the Coliseum and influenced the ensuing report of the reconstruction of Rome in 1925, mainly supported by Gustavo Giovannoni's theory on diradamento and Marcello Piacentini. This report proposed the demolition of the surroundings of Piazza Venezia and the Spina di Borghi (later the Via della Conciliazione). After 1925, ideas on the reconstruction of Rome evolved through proposals such as 'La Grande Roma' by Piacentini or Armando Brasini’s radical demolitions for the centre of Rome. The Piano Regolatore Generale in 1931 gave a final picture to the vision for the Terza Roma that informed later developments of fascist urban transformation. It is relevant that this Piano Regolatore was guided by Giovannoni, Piacentini, Brasini and Cesare Bazzani, a key architect in Terni. ${ }^{12}$

\section{Third episode: the persistence of planned ideas}

The effects of the 1943-1944 bombing changed the course of the events in Terni (Figure 3(a)). Over 40\% of the historical city centre collapsed, with 1,250 dwellings out of 2,500 buildings in the city centre destroyed on 11 August $1943 .{ }^{13}$ At the end of the war, almost $70 \%$ of the city (around $320 \mathrm{Ha}^{14}$ ) had been demolished or badly damaged by the bombing. Consequently, the reconstruction of the city needed to be planned urgently. ${ }^{15}$

\footnotetext{
${ }^{12}$ Aristotle, The Third Rome, 1922-1943. The Making of the Fascist Capital, 25-41.

${ }^{13}$ Comune di Terni, 'Relazione Summaria Sui Danni Arrecati Alla Città Di Terni Da Azioni Di Guerra e Provvedimenti Adottati e Da Adottare per i Lavori Di Riparazione', 4.

${ }^{14}$ Ridolfi, 'Relazione. Piano Di Ricostruzione Della Città Di Terni', 4.

${ }^{15}$ Covino, 'Percezione Della Città e Piani Urbanistici', 70.
} 
On 24 November 1944, Major Comunardo Morelli suggested M. Ridolfi as a trusted architect for undertaking the Piano di Ricostruzione in cooperation with the Commissione di Piano Regolatore founded on 1 June $1943 .{ }^{16}$ As it was considered an emergency plan, the redaction process started on 19 January 1945 and was approved as early as 16 October 1945 by the Giunta Comunale. It received final approval from the central government on 24 March 1949.

The Relazione that accompanied the Piano di Ricostruzione (Figure 2(c)) clearly stated that the new plan followed the 'linea di massima' or master guidelines of the previous Piano Regolatore by Bravetti, Lattes and Staderini in 1937 and the four piani particolareggiati that had already been approved ${ }^{17}$. Within the city centre, the new plan outlined two new crossing streets (one connecting San Salvatore church with Palazzo Spada, and the other by San Pietro church), a similar location for the new market (Quartiere Tacito) and the creation of a new axis at Corso del Popolo. Although some of the new proposals were derived from the opportunity provided by the new voids left by the bombing (for example, the Largo Via Glori, the area around San Francesco or Santo Tommaso), the Corso del Popolo was the result of the strong persistence of the previous plan. This can be observed in a comparison of areas damaged by the bombs and how the new Corso was meant to occupy the blue areas in Figure 3(a), i.e., areas to be demolished according to the Piano Regolatore $1937 .^{18}$

\footnotetext{
${ }^{16}$ Morelli, 'Opere Di Ricostruzione. Provvedimenti Contingibili Ed Urgenti. Richiesta Di Parere All'Architetto Ridolfi. Relazione Del Sindaco Alla Giunta Nella Seduta Del 24 Novembre 1944'.

${ }^{17}$ Ridolfi, 'Relazione. Piano Di Ricostruzione Della Città Di Terni’ .

${ }^{18}$ Coppa, 'Il Piano Regolatore Di Terni: Parte Seconda', 62.
} 
The decision to follow the guidelines of the previous 1937 masterplan guaranteed compliance with the Decreto Lege approved on 1 March 1945, Article no. 1: 'Those partially damaged towns provided with an approved general plan, must coordinate it with their reconstruction plan. The general plan, even after the approval of the reconstruction plan, must be implemented in the areas and for works not included in the new plan'. However, the Relazione Summaria of the Piano di Ricostruzione, kept in Mario Ridolfi's personal archives in Accademia di San Luca, specifically details how the new plan was understood as the combination of both the general criteria of the Commissione di Piano Regolatore and the close-up view of Mario Ridolfi. The Corso del Popolo was proposed in the Relazione from the perspective of 'longitudinal traffic' through Terni's city centre, converging to the central square and improving the 'general systematization of the environment' in the vicinity of Palazzo Spada. ${ }^{19}$ In conclusion, the Relazione declared: 'it could be acknowledged that the demolitions, except for painful losses, have facilitated in a certain sense the implementation of the [1937] plan in its structural lines'.20

It is likely that Mario Ridolfi ultimately understood Corso del Popolo not as an imposition but as a presence that could eventually ease the future of the urban development of Terni southwards. Ridolfi's main concern was not to discuss the sense of the new street but to transform it into a more integrated urban element. As stated by the Commissione Consiliare per il Nuovo Piano Regolatore Generale in a meeting on

\footnotetext{
${ }^{19}$ Ridolfi, 'Relazione. Piano Di Ricostruzione Della Città Di Terni’, 11.

${ }^{20}$ Comune di Terni, 'Relazione Summaria Sui Danni Arrecati Alla Città Di Terni Da Azioni Di Guerra e Provvedimenti Adottati e Da Adottare per i Lavori Di
} Riparazione', 4. 
20 March 1957,21 the Corso del Popolo became, in Mario Ridolfi's hands, a precise and delicate project to solve this 'excessively cold gash in the heart of the city'. It became a way to mediate the gap between town-planning guidelines and the closeness of the fragile historical fabric, between the general arguments of Terni's forma urbis and concerns regarding the skin of the urban space.

\section{Corso del Popolo and the urbanism of 500 metres}

Mario Ridolfi described himself as an 'architetto artigiano' 22 in the way he produced his drawings and approached his designs. He spoke repeatedly about the 'urbanism of 500 metres ${ }^{23}$, referring to the particular size in urban design practice that could be linked with the perceptual field and simultaneously integrate town planning with close attention to the detail and materiality of the architecture: 'designing up to the smallest detail'. ${ }^{24}$ Mario Ridolfi understood town planning as 'architecture on a larger scale', ${ }^{25}$ which reflects his engagement with the various scales of the built environment.

In an interview with the authors on 23 February 2016, Luciano Marchetti confirmed that Ridolfi usually felt uncomfortable in the realm of abstraction and longterm town planning. He was more confident when these works could be embodied in a concrete, tactile, phenomenal approach to an element of built architecture. More

\footnotetext{
${ }^{21}$ Cellini and D'Amato, Le Architetture Di Ridolfi e Frankl, 79.

${ }^{22}$ Ridolfi, 'Progettare per Una Città Di Media Grandezza', 32.

${ }^{23}$ Cf. Tarquini, La Forma Della Città Industriale. Terni. Il Progetto Delle Parti, 99.

${ }^{24}$ Ridolfi, 'Progettare per Una Città Di Media Grandezza', 33.

${ }^{25}$ Tarquini, Terni, Città d'autore: Guida Ad Un Percorso Ridolfiano, 89.
} 
structural planning was delegated to his collaborators. For him, designing cities was a matter of urban craftsmanship, ${ }^{26}$ rather than a complex deductive thought process.

Here, an analysis of the sketches and drawings that led to the final layout of Corso del Popolo could shed light on the value of that project and the innovative design tools that were used to integrate it into Terni's old city centre. Three main design strategies have been identified in this research, which are described below.

\section{3-1937. A Corso del Popolo comprised of streets and squares}

As mentioned, Mario Ridolfi took part in the Piano Regolatore competition in 19321933 and received the exaequo award. Apart from the difference in the geometry of the Corso Littorio (later Corso del Popolo) from the design by Braves, Lattes and Staderini, ${ }^{27}$ the discussion can be focused on a more common aspect: both proposals interpreted this urban project as a combination of a linear element, the essential idea of a street, and the sequencing of squares. While the first element expressed the introduction of the new modern coordinates for Terni and had the same width as the Corso Cornelio Tacito, the second element was meant to resolve its spatial connection with Piazza Vittorio Emanuele and Piazza Solferino (Figures 4(a-d)).

In Ridolfi's project (Figure 4(a)), the new square worked as a main hall in front of Palazzo Spada and as a strategic link between the Corso del Popolo, the new, eastwest sventramento and the system of small spaces leading to Terni's central piazza. The proposal by Braves, Lattes and Staderini (1932-33) more strongly expressed the duality

\footnotetext{
${ }^{26}$ Ridolfi, 'Progettare per Una Città Di Media Grandezza', 32; Pizza, 'La Arquitectura, La Narración, Mario Ridolfi y Sus Huellas’, 239.

${ }^{27}$ Pirro, Enrico Lattes: L'architetto Ritrovato.
} 
between the linearity of Corso Littorio and the new piazza linking the Palazzo Spada with the San Salvatore church (Figure 4(b)). However, a similar strategy can be found in the use of a new square as an 'interlocking space' ${ }^{28}$ connecting the Corso with the existing public squares. The final plan approved in 1937 (Figure 4(c)) continued with this scheme but opened a new east-west axis in the configuration of the new square.

The configuration of Piazza Vittorio Emanuele became a matter of discussion. Architects such as Cesare Bazzani worked extensively in Terni between 1901 and 1939, and in 1933 worked on the replacement of the existing church of San Giovanni Decollato in Piazza Vittorio Emanuele with the new Palazzo delle Poste. ${ }^{29}$ The Palazzo was built in 1936. From 1937, Bazzani worked in parallel on the adaptation of the piazza to the new provisions of the Piano Regolatore approved the same year. His design was inspired by Bravetti's: drawing a gentle curve towards the new Corso del Popolo, thus pushing into second place continuity towards the former cardus and erasing the square that both Ridolfi and Staderini had proposed in their designs (Figure 4(d)). Other relevant projects include one in June 1933 by engineer Angelo Guazzaroni (exaequo in the 1933 competition with an entry entitled 'Terni Fascista') or a project by Emanuele Caniggia in $1944 .{ }^{30}$ In 1985, Carlo Aymonino drew his project 'Tre piazze a Terni'; a more recent design that is worthy of an in-depth study.

Beyond the differences in scope and quality, all the aforementioned designs questioned the role of the spatial link between the new Corso del Popolo and the existing system of piazzas in the potential success of the project. Solving the Corso del

\footnotetext{
${ }^{28}$ Bacon, Design of Cities, 69.

${ }^{29}$ Bazzani, Giorgini, and Tocchi, Cesare Bazzani: Un Accademico d'Italia.

${ }^{30}$ Emanuele, 'Il Nuovo Piano Di Ricostruzione'.
} 
Popolo was not just a matter of building heights, porticoes or setbacks, but a complex issue based on effective, rich articulation with the existing system of public squares.

\section{4-1949. Corso del Popolo under the shape of the movement}

The working drawings that Ridolfi and Frankl produced after the 1944 bombing for the Piano di Ricostruzione comprise a second phase in the development of the final solution for Corso del Popolo (Figure 4 (e-h)). Although no chronological evidence has been found in the order of the sketches, two main arguments can be identified:

The first group was mainly guided by the introduction of traffic logic that affected the old fabric. Images such as Figure 4(e) show how, to some extent, the problem of rebuilding the city after the bombing was neither a matter of squares and streets nor a more general discussion about the city's new coordinate system. Instead, it was focused on facilitating movement flows. As the drawing itself expresses, working with forms of mobility meant the introduction of new urban structures such as ring roads and, more dramatically, the continuity of some important cross streets that irrigated the heart of the city. The modernity of mid-twentieth century sventramenti was related to radius of movement and continuity rather than the perspective of representation and hygiene. As declared in the Relazione of the Piano di Ricostruzione, the Corso del Popolo was thus considered a key strategic link within a more general structure designed for the automobile. ${ }^{31}$

This approach led to studies such as Figure 4 (e), in which the previous concatenation of linear elements and squares proposed in the 1930s was deliberately blurred into an ambiguous form of wide streets or linear squares. The previous

\footnotetext{
${ }^{31}$ Ridolfi, 'Relazione. Piano Di Ricostruzione Della Città Di Terni’.
} 
appealing assemblage of spaces and diagonals could now be solved by the continuous form of the movement flow and the subsequent introduction of eroded corners, curvilinear traces of traffic and new roundabouts to channel the streams. Mario Ridolfi's layout remained in a tense equilibrium between the echoes of Camillo Sitte's urban design theories ${ }^{32}$ and echoes of Italian Futurism's fascination with movement and speed as the source of new urban energy: form should follow the flow. Thus, Corso del Popolo appeared as a wide river of movement in which the existing buildings, such as Palazzo Spada, remained as static cobblestones.

In parallel, a second group of drawings (Figures $4(\mathrm{f}-\mathrm{g})$ ) explored the dichotomy between the linear Corso del Popolo, embedded in a new urban grid, and the organic assembly of squares around Palazzo Spada. Figure 4(h) correspond to the final version of the Piano di Ricostruzione (1949) and might be considered a long exploration of a mediating form that could help to solve the integration of these two formal orders: flow and pause, linearity and concavity.

\section{7-1959. Corso del Popolo and the depiction of the 'squared street'}

Following the prescriptions of the Legge Urbanistica Nazionale 1150/1942, ${ }^{33}$ in March 1955 architects Mario Ridolfi and Alberto Staderini were both commissioned to undertake the new Piano Regolatore Generale (PRG) for Terni; a document that was initially approved in March 1962 and whose application began in October 1967. On 23 May 1956, Staderini declined the offer (see original manuscript CD180-XV at Accademia di San Luca) and was replaced by Giovanni Possenti.

\footnotetext{
32 Sitte, Der Städtebau Nach Seinen Künstlerischen Grundsätzen.

${ }^{33}$ Fantozzi Micali, Piani Di Ricostruzione e Città Storiche: 1945-1955.
} 
According to the correspondence between Ridolfi and the Municipality of Terni, different tempos were used to draw up the $P R G$ : the territorial and municipal planning strategies for Terni and the detailed implementation plans for the Corso del Popolo area. While the two strategies involved a long, hazardous process of redaction and approval ${ }^{34}$, the implementation plans followed their own parallel path. From the first report on 10 June 1957 entitled Breve relazione dei compilatori del Nuovo Piano Regolatore sulla necessità della salvaguardia delle aree centrali nella città di Terni (CD180-LV) to the document Relazione of the Variante al Piano di Ricostruzione corso del Popolo, piazza del Popolo e zone adiacenti (CD180-LXIX) on 15 September 1957 and the final presentation to the Municipality on December of the same year, intense work was undertaken to produce a definite solution for this degraded part of the city. As stated in the letters sent to the Municipality of Terni on 7 June (CD180-CXXXI) and 14 October 1958 (CXLIII), Mario Ridolfi declared an urgent need to approve this document outside of the regular timing of the $P R G$. The Variante was finally approved on April 1959 and, in general terms, the experience of Corso del Popolo might be regarded as an executive project $^{35}$ that was meant to test the town-planning strategies outlined at the $P R G$ (Figure 3(b)). The Corso del Popolo's plan was incorporated as one of the Piani

Particolareggiati that informed the transformation of the city centre at the Piano Regolatore Generale.

From another perspective, a new design strategy was envisaged for this final proposal of the Corso del Popolo adopted in 1959 (Figure 4(i) and 5): the previous

\footnotetext{
${ }^{34}$ Cellini and D'Amato, Mario Ridolfi All'Academia Di San Luca.

${ }^{35}$ Fraticelli, 'Terni: Progetto e Città', 76.
} 
dichotomy between the linear street and the sequence of squares was approached through interaction between both categories. Now the street could be imagined more as a 'necklaces of squares' or, as Aldo Tarquini stated, 'a continuous system of differentiated cells'. ${ }^{36}$

Mario Ridolfi himself explained in the Relazione manuscript that introduced the Variante al Piano di Ricostruzione Corso del Popolo that, according to the guidelines on the new in-progress Piano Regolatore Generale, the Corso del Popolo would lose its function as a longitudinal traffic artery for the city. Accordingly, it was more appropriate 'to modify its characteristics (...)from the perspective of aesthetics'. Ridolfi described the new layout as follows: 'The street has kept the original axis, but it will no longer be shaped by a monotonous succession of porticoed buildings of the same height (five-and-a-half storeys), arranged along the same alignment and only interrupted by a new cross street. Instead, it will adopt a more civic character, it will follow the succession of different episodes, the most important of which is found between Palazzo Spada and the Church of S. Salvatore, and it will end in Piazza del Popolo'.${ }^{37}$ It is a street comprised of a rhythm of urban episodes, a street made of a varied yet harmonic composition of new architectures, trying 'to ease the transition between the existing buildings of Via Roma and that will define the new street'. ${ }^{38}$

\footnotetext{
${ }^{36}$ Tarquini, Terni, Città d'autore: Guida Ad Un Percorso Ridolfiano, 12.

${ }^{37}$ Ridolfi, 'Relazione. Variante Al Piano Di Ricostruzione Corso Del Popolo. Piazza Del Popolo e Zone Adiacenti', 2.

${ }^{38}$ Ibid.
} 
The building setbacks generated a layout of public space that was the extension of the organic order of piazzas to build a new street, a 'squared street', rather than the prolongation of the linearity of the Corso towards the city centre. Unlike a conventional street, the new squared street highlighted the preponderance of corners rather than the skewed vision of plain façades, the sequence of thresholds rather than the continuity of alignments and the force of verticality rather than the horizontal lines. The setbacks of the final masterplan for Corso del Popolo ${ }^{39}$ might therefore be regarded as a result of an extension of the open space structure of Piazza Vittorio Emanuele and Piazza Solferino, rather than a direct response to the existing pattern of the old fabric. The resulting public space offered an inner paradox by joining both the expression of static urban rooms and movement logic, the intricacies of the traffic flows -the so-called 'rotazione viaria' condition mentioned by Mario Coppa ${ }^{40}$ - and the regular geometry of the alignments.

However, such a unique layout should not be considered an invention of Mario Ridolfi stricto sensu, but an innovative evolution of previous references. There is a strong connection with the architect Marcello Piacentini, of whom Ridolfi wrote: 'Marcello Piacentini taught me all about town planning. Piacentini was too much of an architect to do urban planning, he did it like an architect does: as a city sculptor' ${ }^{41}$ It is relevant that Marcello Piacentini was not only young Mario Ridolfi's master, but also part of the jury that awarded his Fontana in Piazza Tacito in $1932 .{ }^{42}$ The associations

\footnotetext{
${ }^{39}$ Clua, 'La Arquitectura Del Swing. Sutilezas y Perturbaciones de La Forma Urbana'.

${ }^{40}$ Coppa, 'Il Piano Regolatore Di Terni: Parte Seconda', 67.

${ }^{41}$ Bellini, Mario Ridolfi, 80.

${ }^{42}$ Tarquini, La Forma Della Città Industriale. Terni. Il Progetto Delle Parti, 87.
} 
between Corso del Popolo and Piacentini's work can be seen in some of his projects, such as the decalage of the perimeter of the new Piazza della Vittoria in Brescia (1928$1932)^{43}$ and Piazza Dante in Napoli (1937-41) or in the extensive use of porticoes in the Via Roma Nuova of Torino (1934-1935). Beyond the evident difference in the attributes that inspired and signified Piacentini's style, Mario Ridolfi's Corso del Popolo might be considered the application of the same spatial concepts, now influenced by the culture of neorealism ${ }^{44}$ translated into the conception of urban planning.

The Corso del Popolo's design strategy can also be traced to the extensive production of new housing districts guided by INA Casa from 1949. Among them, the Quartiere Tiburtino, developed by Mario Ridolfi from 1949 to 1954 in collaboration with Ludovico Quaroni, explored the possibilities of an irregular aggregation of housing typologies and the ensuing generation of a varying number of intermediate collective spaces. Skewed geometries, warm colours and materials, inclined roofs and a wide spectrum of typologies were used to achieve a varied, human-scale urban landscape. Other projects by Mario Ridolfi such as the Edifici INA Casa, called 'case siamesi' in Terni (1949-1951), explored similar concepts to the Corso del Popolo, such as how to address the regularity of rational, strict repetition of sun-oriented blocks given by the urban layout by including subtle setbacks, diagonals and shifts in the location and geometry of each block to generate varied open spaces.

\footnotetext{
${ }^{43}$ Pacini, 'La Sistemazione Del Centro Di Brescia Dell'architetto Marcello Piacentini'.

${ }^{44}$ Ridolfi, 'Progettare per Una Città Di Media Grandezza'; Canella, 'Maestri Razionalisti e Neorealisti Italiani Nell'era Dei Graffiti?'
} 
The origins of Corso del Popolo's layout can also be connected to a more general framework of references. German architect Wolfgang Frankl had a strong influence, as he started work in Mario Ridolfi's office in 1934. As stated by Luciano Marchetti in the interview, he inspired most of the strategic conception of the urban planning and, more specifically, he could have informed Ridolfi about the work of his former collaboration with Luigi Piccinato. Sabaudia's central square, designed in his Piano Regolatore 1933-1948, might have inspired Corso del Popolo's vibrating layout and use of porticoes, although differences in density and context should be acknowledged.

Wolfgang Frankl also helped introduce Mario Ridolfi to German architectural culture. In 1934, Mario Ridolfi travelled with Dieter Österlen to Germany and Switzerland and was impressed by Bauhaus rationalism and German expressionism. ${ }^{45}$ He formed a strong friendship with German architect Konrad Wachsmann, a great connoisseur of Tessenow's research. These references, together with his strong connection to the Accademia Tedesca in Villa Massimo, Roma, might explain the echoes of German urban planning.

For instance, the design strategies underlying the Corso del Popolo could be regarded as an echo of the controversy between straight or crooked streets, introduced by Joseph Stübben in 1877 and popularized by Karl Henrici's comparison with Camillo Sitte's City Planning According to Aesthetic Principles (1889).$^{46}$ Echoes of the Civic

\footnotetext{
${ }^{45}$ Bonaccorso, 'Mario Ridolfi e La Cultura Tedesca: Frequentazioni, Influenze e Progetti Tra Il 1933 e Il 1938'.

${ }^{46}$ Boyd Whyte, Modernism and the Spirit of the City, 60; Sonne, Urbanity and Density in 20th Century Urban Design, 121.
} 
Art movement influenced by Albert Brinckmann, Werner Hegemann or Gustavo Giovannoni in Italy could also be highlighted ${ }^{47}$ Similar design arguments as in Corso del Popolo can be found, for example, in projects such as the Strasse des 18. Oktober in Lepzig, 1916, published in The American Vitruvius. ${ }^{48}$ In fact, Mario Ridolfi visited that city and was probably inspired by the porticoes and setbacks in the layout of this street between Härtelstrasse and Dimitroffstrasse. Other examples such as Cornelis Van Eesteren's entry for the competition of Unter den Linden in 1925 or the setbacks included by Erik Gunnar Asplund in his entry for the Götaplatsen's competition in 1917, Göteborg, ${ }^{49}$ might not have been familiar to Mario Ridolfi, but they indicate a similar field of interest in concern for the shape of the public space.

Following the broader spectrum of design strategies, Corso del Popolo could be linked to the dichotomy shown in 1921 by Le Corbusier between the rue corridor and the rue à redents. The idea of the redents was influenced by the Fröbel game, the boulevard à redants of Eugène Hénard or Auguste Perret or the development of large social utopian housing complexes such as the Phalanstere, ${ }^{50}$ which gave Le Corbusier a rich spatial variability in the continuous system of streets and façades. In fact, the modern open space envisaged by the master was not meant to be boundless, but an environment limited by the buildings themselves and the vegetation. ${ }^{51}$ Hence, the redents were a synthetic answer to both the openness of Modernity and the required

\footnotetext{
${ }^{47}$ Sonne, Urbanity and Density in 20th Century Urban Design.

${ }^{48}$ Hegemann and Peets, The American Vitruvius: An Architects' Handbook of Civic Art.

${ }^{49}$ Blundell, Gunnar Asplund, 84.

${ }^{50}$ González Cubero, 'Endurance and Transformation in Le Corbusier's Redent'.

${ }^{51}$ Corbusier, Urbanisme, 225.
} 
closeness of human perception. ${ }^{52}$ As a result, the public space created in-between the bàtiments à redants could be considered 'a street, square or park all at once'. ${ }^{53}$

It is not hard to imagine the influence of such a modern paradigm in Ridolfi's project. The systematic setbacks of the buildings echoed a micro-scaled, purposeful application of the rue à redants' urban layout. However, the resulting open space was neither a vast and formless ground nor an interstitial place between figures. In the squared street, the open space was interpreted as a figure with its own identity and attributes, dimensioned highly accurately (Figure 5). As in a still life painted by Giorgio Morandi, ${ }^{54}$ the proximity and articulation between the urban elements, the subtle displacement of the façades and the strategic position of the unrealized project for the Palazzo per Uffizi Comunale produced something beyond a Modern Movement's juxtaposition of elements or even more than a parataxis. ${ }^{55}$ The resulting masterplan introduced inflection as a way to create urban coherence and the interplay of tense and interesting distances,${ }^{56}$ to produce a higher level of relationships and, therefore, urbanity.

\footnotetext{
${ }^{52}$ González Cubero, 'Endurance and Transformation in Le Corbusier's Redent'.

${ }^{53}$ Ibid., 72.

${ }^{54}$ Feduchi, 'Mario Ridolfi: El Dibujo y La Renuncia'.

${ }^{55}$ Prosperetti, ‘La Apertura Del Corso Del Popolo En Terni: Un ‘Sventramento’ de Mario Ridolfi'.

${ }^{56}$ De Solà-Morales, A Matter of Things, 171-73.
} 
Indeed, although Prosperetti ${ }^{57}$ and Fraticelli58 ${ }^{58}$ argued that Mario Ridolfi did not follow a systematic analysis and in-continuity approach to the historic type morphology of Terni's buildings, it could be stated that an intuitive, powerful reading of the form of the existing open spaces was developed through sketches, photographs and visits undertaken from 1933. Ridolfi's layout expressed an understanding of the city as a text that should be read and evolved, rather than as a passive context or pretext.

\section{A city comprised of palazzinas}

The process of reconstructing European cities after World War II raised the issue of whether to regenerate historical fabrics or explore rational, economical ways of producing new housing. ${ }^{59}$ Cities like Dresden or Warsaw were rebuilt according to the previous urban form. In contrast, cities such as Saint Dié by Le Corbusier (1945) were planned to be rebuilt from scratch by introducing the ideas of modern architecture and planning prompted by the CIAM. The new modern vision addressed urgent social needs for new dwellings through repetition and combination of essential typologies such as blocks and towers, located in large open spaces. In the end, as stated by Manuel de Solà-Morales, ${ }^{60}$ modern urban planning envisioned the construction of new urban conditions through the rational aggregation of minimum housing units at citywide scale,

${ }^{57}$ Prosperetti, 'La Apertura Del Corso Del Popolo En Terni: Un ‘Sventramento’ de Mario Ridolfi', 26.

${ }^{58}$ Fraticelli, 'Terni: Progetto e Città', 76.

${ }^{59}$ Pendlebury, Erten, and Larkham, Alternative Visions of Post-War Reconstruction. Creating the Modern Townscape.

${ }^{60}$ De Solà-Morales, 'La Segunda Historia Del Proyecto Urbano'. 
leaving a disciplinary gap between the scale of architecture and urban planning.

Mario Ridolfi's experience in Terni illustrates an intermediate path between both models of reconstruction, that is, between the strict replication of the historical urban fabric and the application of modern concepts, starting from scratch. ${ }^{61}$ Using the duality that Colin Rowe and Fred Koetter promoted in Collage City (1975), Ridolfi's masterplan could be seen as a work of bricolage between the opposing models of modern urban planning and the figure-ground pattern of the historical city: 'on one side of the equation, building becomes prime and insulated, on the other the isolation of identifiable space reduces (or elevates) the status of building to infill' ${ }^{62}$ The Variazione for the Corso del Popolo presented in 1959 could be regarded as a clear link between the 'modern utopia' and the contingencies of the townscape approach, between the design attitudes represented by the 'hedgehog' and the 'fox'. ${ }^{63}$

In addition, Corso del Popolo's mid-scale is relevant because it integrated both research on architecture typology and urban planning. Mediation between both fields was solved though a free-standing building typology, namely the palazzina. ${ }^{64}$ Just as the sequencing of urban rooms was the key formal argument for the design of the Corso del Popolo sventramenti, now the palazzina, a non-vernacular typology of Terni, became

\footnotetext{
${ }^{61}$ Feduchi, 'Memoria y Lugar: Una Reflexión Sobre La Actuación de Mario Ridolfi y Wolfgang Frankl En Torno Al Palacio Spada de Terni’, 128.

${ }^{62}$ Rowe and Koetter, Collage City, 78.

${ }^{63}$ Ibid., 91.

${ }^{64}$ Andriani, 'Palazzine Romane Di Mario Ridolfi: Dalla Rea Alla Zaccardi, Alterazione Distorsione e Corruzione Della Figura Razionalista'.
} 
the basic cell to build the new modern landscape of that quartiere, to update the inner core of the city and to predict the future expansion of Terni's peripheries.

Mario Ridolfi had been researching this typology since 1927, when he participated in a competition for a palazzina signorile in Rome or, above all, since 1931 with his works for the II Esposizione Italiana di Architettura Razionale Italiana. Here he envisaged a $25 \times 25$ m palazzina including 24 dwellings organized around a central core formed by two light wells and staircases. Each dwelling was considered an aggregation of interlocked rooms that formed a dense and compact body, rather than a modern fluent space. Ridolfi moved from understanding the façade as a plain surface, to its volumetric expression. Each dwelling was defined by two façades building a corner, rather than by a single façade or a front and a rear façade. A central room was meant to be the main space in the dwelling, connected by views and access to the other rooms and defining a skewed promenade and an enfilade effect. The room, the corner and the diagonal relationships could be regarded as three clear echoes of the urban arguments in the Corso del Popolo's layout, applied to the scale of the dwelling: from the 'squared street' to that 'made of rooms'. ${ }^{65}$

The tense encounter between the city's structure and the building typology was outlined by drawing freehand (or 'mano libera') the position of each element according to a soft grid pattern. ${ }^{66}$ With this drawing method, Mario Ridolfi aimed to avoid possible rigidities and induce subtle deformations and adaptations to fit them better into Terni's fragile fabric. As Auguste Perret had experienced with a 6,24 m grid to give a unique sense of order throughout the scales of Le Havre (1946-1950), the use of the grid

\footnotetext{
${ }^{65} \mathrm{Cf}$. Sergison and Bates, Papers 3, 180.

${ }^{66}$ Ridolfi, 'Progettare per Una Città Di Media Grandezza', 32.
} 
by Ridolfi might be also understood as a tool to integrate the different scales of the project.

The embedding of these pure geometrical typologies into Terni's urban fabric followed three design strategies: precise sizing of each building according to inner functions and public space constraints, aggregation of volumes to ensure urban continuity and acute orientation to adapt buildings to the context and produce tense public space. Mario Ridolfi employed these tools to carefully adjust the distances between buildings, thus allowing for the creation of clusters of new and old architectures. Examples such as the three Franconi apartment blocks (1959-1962, 20x22.5 m; 15x29 m; 16x22 m) reveal a powerful combination of volumes articulating the extension of the Corso del Popolo main street and its encounter with the axis Viale Spada to River Nera (Figure 6). In turn, the two Pallotta apartment blocks (1960-1964, $20 \times 26 \mathrm{~m}$ ) used the same urban language and comprised a multifaceted enclosed urban space together with Palazzo Spada and the future Palazzo per Uffici Comunali. ${ }^{67}$ In the case of the Fratelli Briganti apartment building and store (1959-1964), Ridolfi explored how an isolated building of $29 \times 29 \mathrm{~m}$ could create a bead of square-like spaces just by

\footnotetext{
${ }^{67}$ Polin, 'Mario Ridolfi, Volfango Frankl, Domenico Malagricci. Nuovo Palazzo per Uffici Del Comune Di Terni’; Feduchi, ‘Memoria y Lugar: Una Reflexión Sobre La Actuación de Mario Ridolfi y Wolfgang Frankl En Torno Al Palacio Spada de Terni’; Soto, 'Forma y Lugar'; Cavallari, Ridolfi e Frankl: Progettare e Costruire. Il Nuovo Palazzo per Uffici Comunali a Terni; Tarquini, La Città Di Mario Ridolfi,
} 229-39. 
its position and rotation, thus becoming a 'great hinge not only for the urban fabric but also between the old and the modern parts of a transformed historical centre' ${ }^{68}$

As a corollary of these design strategies, the introduction of outdoor covered porticoes in these palazzinas is of note: a double-height portico in Fratelli Briganti's building, the passageway in Franconi's complex and the linear one in Pallotta's. These strange elements in Terni's typology might be regarded not only as a precise tool to address the merging of pure solid palazzinas with the urban fabric, but also as a synthetic expression of the cross-scaling approach that Ridolfi displayed in his architecture and in his way of building the city, intermingling the private and the public realm. ${ }^{69}$

${ }^{68}$ Tarquini, La Forma Della Città Industriale. Terni. Il Progetto Delle Parti, 91.

${ }^{69}$ Andreani, 'Le Case Franconi in Corso Del Popolo'. 


\section{Conclusions: towards a renewed understanding of artisan city planning}

Some concluding remarks could be addressed here, relating to the question established at the start of the paper. First, an analysis of the history of plans and ideas preceding Ridolfi's Corso del Popolo reveals that the value of his milestone project lies in his capacity to integrate top-down premises into the fine grain of the historic city, rather than in the decision underlying the strategic axis towards Terni's centre.

Ridolfi's drawings and sketches from 1932 to 1959 also depict the squared street or the street composed of a bead of urban rooms. This is a powerful, evocative mediating approach between the pattern of rue corridor and the system of squares in Terni's city; between the historical city pattern and the open-space paradigm of urban functionalism.

In a more general framework, the layout of Corso del Popolo could be considered a modern application of the design strategy underlined by Sir E. Bacon in his acute analysis of the Greek urban 'growth by accretion', in which open space works as a 'connector' and 'coherence is maintained by the tension between buildings across the angular space' ${ }^{70}$ The 'creative tension' that Bacon found in some Baroque architectural projects was used in Terni as the key design tool. The accuracy in the distances and dimensions between buildings that was clearly defined in the normative document approved in 1959 could be interpreted in this way.

Fourthly, Corso del Popolo's plan could be interpreted not just as a major modernization operation for the city centre, but also a suitable scenario for testing delicate and innovative collective housing. This is conveyed in both the architecture and urban planning conveyed through the application and variations of the palazzina

\footnotetext{
${ }^{70}$ Bacon, Design of Cities, 68.
} 
typology. The use of palazzina by Ridolfi managed to integrate into the domestic domain a richness akin to that which squared streets had provided in the public realm. The palazzina, as a house comprised of rooms, established this relation between the city's structure and the housing typology in a conceptual continuity between domestic and urban ideas in Terni's fragile fabric.

The Corso del Popolo reveals specific implementation plans' ability to shape the forma urbis as a whole and their capacity to reach the detailed scale of the dwelling. ${ }^{71}$ Conversely, the detailed design of the Fratelli Briganti, Pallotta or Franconi buildings proves the powerful capacity of urban planning to inspire meaningful architecture of the city, albeit by understanding planning not 'as abstract zoning but as an architecture project developed at an urban scale'. ${ }^{72}$ The resulting collage of the Piani Particolareggiati designed by Mario Ridolfi and Wolfgang Frankl that followed the Variazione of Corso del Popolo might express a way of addressing the planning of cities through the concatenation of parts (Figure 7).

Finally, Mario Ridolfi's experience of glissement d'échelles in Corso del Popolo might be vindicated as a key episode in a hidden history of the urban planning beneath the epigones of modern functionalism. As clearly defined in the journal Casabella no. 487 (1983) and later confirmed by Manuel de Solà-Morales in the aforementioned article "The second history of the urban project"73, it is of interest to examine this tradition 'between the architecture of buildings and town planning', to retrace the confluence between these disciplines, not as a matter of mere further detailing but as a

\footnotetext{
${ }^{71}$ Ercolani, 'Architettura Di Ridolfi a Terni', 87.

72 Portoghesi, 'Presenza Di Ridolfi', 9.

${ }^{73}$ De Solà-Morales, 'La Segunda Historia Del Proyecto Urbano'.
} 
real interaction between the form of the city and the discussion of its architecture. The relevance of this topic might be justified, for example, by recent research such as Wolfgang Sonne's work on the twentieth century 'urbane dense city'74 or Brent D. Bryan's recent exploration of the theoretical foundation of urban design as the largest of the building arts. ${ }^{75}$

Therefore, this paper could open up a future line of research on a particular, bottom-up way of shaping the built environment almost as a matter of craftmanship, illustrated by the fertile interaction between architects and their cities. Inspired by preeminent examples such as Palladio in Vicenza or K. F. Schinkel in Berlin, on-going research is designed to explore the scope, design strategies and potential of '500-metre' urban planning. Relevant examples are Gustav Gull in Zürich, Theodor Fischer in Münich, Giovanni Muzio in Milan, Jože Plečnik in Ljubljana, Wilhem Marinus Dudok in Hilversum, Fritz Schumacher in Hamburg, Mario Ridolfi in Terni, GianCarlo de Carlo in Urbino and, more recently, K.R. Schättner in Eichstätt or Luigi Snozzi in Monte Carasso. In all of these examples, similar planning strategies can be found, with ways to move from abstract deductive thinking to approaching planning in cities as a craft-centred, tactile endeavour that can overcoming the constraints of authorship and become the material representation of a society's memory and culture.

\section{Disclosure statement}

No potential conflict of interest was reported by the authors

\footnotetext{
${ }^{74}$ Sonne, Urbanity and Density in 20th Century Urban Design.

${ }^{75}$ Ryan, The Largest Art: A Measured Manifesto for a Plural Urbanism.
} 


\section{Geolocation information.}

$42^{\circ} 33^{\prime} 37.0^{\prime \prime} \mathrm{N} 12^{\circ} 38^{\prime} 49.0^{\prime \prime E ~ T e r n i, ~ I t a l y ~}$ 
Andreani, Francesco. 'Le Case Franconi in Corso Del Popolo'. In Mario Ridolfi Architetto 1904-2004, edited by Renato Nicolini, 176-86. Milano: Electa, 2005.

Andriani, Carmen. 'Palazzine Romane Di Mario Ridolfi: Dalla Rea Alla Zaccardi, Alterazione Distorsione e Corruzione Della Figura Razionalista'. Rassegna Di Architettura e Urbanistica 89-90 (1996): 122-29.

Aristotle, Kallis. The Third Rome, 1922-1943. The Making of the Fascist Capital. New York: Palgrave McMillan, 2014.

Bacon, Edmund N. Design of Cities. London: Thames and Hudson, 1978.

Bazzani, Cesare, Michele Giorgini, and Valter Tocchi. Cesare Bazzani: Un Accademico d'Italia. Perugia: Electa/Umbri Associati, 1988.

Bellini, Federico. Mario Ridolfi. Roma: Laterza, 1993.

Blundell, Peter. Gunnar Asplund. New York: Phaidon, 2006.

Bonaccorso, Giuseppe. 'Mario Ridolfi e La Cultura Tedesca: Frequentazioni, Influenze e Progetti Tra Il 1933 e Il 1938'. In Mario Ridolfi Architetto 1904-2004, edited by Renato Nicolini, 107-14. Milano: Electa, 2005.

Boyd Whyte, Iain. Modernism and the Spirit of the City. London: Routledge, 2003.

Brunetti, F. Mario Ridolfi. Firenze: Alinea, 1985.

Canella, Guido. 'Maestri Razionalisti e Neorealisti Italiani Nell’era Dei Graffiti?' Hinterland 13-14 (1980): 2-3.

Cavallari, Luigi. Ridolfi e Frankl: Progettare e Costruire. Il Nuovo Palazzo per Uffici Comunali a Terni. Pescara: Sala Editori, 2000.

Cellini, Francesco. 'Su Mario Ridolfi. Geometria e Costruzione Della Pianta Centrale'. Lotus International 37 (1983).

Cellini, Francesco, and Claudio D'Amato. Le Architetture Di Ridolfi e Frankl. Milano: Electa, 2005. - Mario Ridolfi All'Accademia Di San Luca: Edizione Critica Del Corpus Dei Disegni Di Architettura e Dei Documenti Dello Studio Ridolfi e Fondo RidolfiFrankl Malagricci (1924-1984) Dell'Archivio Dell'Accademia Nazionale Di San Luca. Roma : Graffiti, 2003. 
Cellini, Francesco, Claudio D'Amato, and Valerio Palmieri. Mario Ridolfi: Manuale Delle Tecniche Tradizionali Del Costruire: Il Ciclo Delle Marmore. Milano : Electa, 1997.

Clua, Álvaro. 'La Arquitectura Del Swing. Sutilezas y Perturbaciones de La Forma Urbana'. Palimpsesto 9 (2014): 6-7.

Comune di Terni. 'Relazione Summaria Sui Danni Arrecati Alla Città Di Terni Da Azioni Di Guerra e Provvedimenti Adottati e Da Adottare per i Lavori Di Riparazione'. Terni, 1945.

Coppa, Mario. 'Il Piano Regolatore Di Terni: Parte Seconda'. Urbanistica 35 (1962): $59-72$.

—_. 'Il Piano Regolatore Di Terni'. Urbanistica 34 (1961): 69-76.

Corbusier, Le. Urbanisme. Paris: Crès, 1925.

Covino, Renato. 'Percezione Della Città e Piani Urbanistici'. In La Città Di Mario Ridolfi: Architettura, Urbanistica, Storia, Arte, Cinema, Fotografia, edited by Aldo Tarquini. Roma: De Luca Editori d'Arte, 2005.

Cristofori, Cecilia. Terni e Bilbao. Città Europee Dell'acciaio. Milano: Franco Angeli, 2014.

De Solà-Morales, Manuel. A Matter of Things. Rotterdam: Nai, 2008.

—. 'La Segunda Historia Del Proyecto Urbano'. Revista UR 5 (1987): 21-27.

Emanuele, Caniggia. 'Il Nuovo Piano Di Ricostruzione'. L'Umbria Democratica. 19 November 1949.

Ercolani, Giampaolo. 'Architettura Di Ridolfi a Terni'. Controspazio 3 (1974): 84-101.

Fantozzi Micali, Osanna. Piani Di Ricostruzione e Città Storiche: 1945-1955. Firenze: Alinea Editrice, 1998.

Feduchi, Pedro. 'Mario Ridolfi: El Dibujo y La Renuncia'. Arquitectura 290 (1992): $110-16$.

—. 'Memoria y Lugar: Una Reflexión Sobre La Actuación de Mario Ridolfi y Wolfgang Frankl En Torno Al Palacio Spada de Terni'. Arquitectura 271-272 (1988): 124-33. 
Fraticelli, Vanna. 'Terni: Progetto e Città'. Controspazio 3 (1974): 74-83.

Fuselli, Eugenio. 'Il Concorso Nazionale per Il Piano Regolatore Di Terni'. Architettura, no. 2 (1934): 107-17.

González Cubero, Josefina. 'Endurance and Transformation in Le Corbusier's Redent'. Journal of Architecture and Urbanism 40, no. 2 (2016): 60-74. doi:10.3846/20297955.2016.1194604.

Hegemann, Werner, and Elbert Peets. The American Vitruvius: An Architects' Handbook of Civic Art. New York: Architectural Book, 1922.

Morelli, Comunardo. 'Opere Di Ricostruzione. Provvedimenti Contingibili Ed Urgenti. Richiesta Di Parere All'Architetto Ridolfi. Relazione Del Sindaco Alla Giunta Nella Seduta Del 24 Novembre 1944', 1944.

Moschini, Francesco, and Luciana Rattazzi, eds. Mario Ridolfi. La Poetica Del Dettaglio. Roma: Kappa, 1997.

Nicolini, Renato. Mario Ridolfi: Architetto : 1904-2004. Milano: Electa, 2005.

Pacini, Renato. 'La Sistemazione Del Centro Di Brescia Dell'architetto Marcello Piacentini'. Architettura, no. 12 (1932): 649-73.

Palmieri, Valerio. Mario Ridolfi. Guida All'architettura. Verona: Arsenale Editrice, 1997.

Pendlebury, John, Erdem Erten, and Peter J. Larkham, eds. Alternative Visions of PostWar Reconstruction. Creating the Modern Townscape. New York: Routledge, 2015.

Pirro, Danilo Sergio. Enrico Lattes: L'architetto Ritrovato. Roma: Gangemi Editore, 2013.

Pizza, Antonio. 'La Arquitectura, La Narración, Mario Ridolfi y Sus Huellas'. In Mario Ridolfi (1904-1984). La Arquitectura de Ridolfi y Frankl, edited by Ricardo Sánchez and Lucas Recuenco, 231-40. Madrid: Ministerio de Obras Públicas y Transportes, 1991.

Polin, G. 'Mario Ridolfi, Volfango Frankl, Domenico Malagricci. Nuovo Palazzo per Uffici Del Comune Di Terni’. Casabella 489 (1983).

Portelli, Alessandro. Biografia Di Una Città. Storia e Racconto: Terni 1830-1985. 
Torino: Giulio Einaudi, 1985.

Portoghesi, Paolo. 'Presenza Di Ridolfi'. Controspazio 1 (1974): 6-11.

—. 'Una Città d'autore'. In Terni Città d'autore: Guida Ad Un Percorso

Ridolfiano, edited by Aldo Tarquini. Terni: Comune di Terni, 1996.

Prosperetti, Francesco. 'La Apertura Del Corso Del Popolo En Terni: Un

"Sventramento" de Mario Ridolfi'. Arquitecturas Bis 21 (1978).

Ridolfi, Mario. 'Progettare per Una Città Di Media Grandezza'. Hinterland 13-14 (1980): $30-35$.

—_. 'Relazione. Piano Di Ricostruzione Della Città Di Terni'. Terni, 1945.

—. 'Relazione. Variante Al Piano Di Ricostruzione Corso Del Popolo. Piazza Del Popolo e Zone Adiacenti', 1957.

Rowe, Colin, and Fred Koetter. Collage City. Cambridge, Massachusetts: The MIT Press, 1978.

Ryan, Brent D. The Largest Art: A Measured Manifesto for a Plural Urbanism. Cambridge: The MIT Press, 2017.

Sánchez, Ricardo, and Lucas Recuenco, eds. Mario Ridolfi (1904-1984). La Arquitectura de Ridolfi y Frankl. Madrid: Ministerio de Obras Públicas y Transportes, 1991.

Sergison, Jonathan, and Stephen Bates. Papers 3. Luzern: Quart Architektur, 2015.

Sitte, Camillo. Der Städtebau Nach Seinen Künstlerischen Grundsätzen, 1889.

Sonne, Wolfgang. Urbanity and Density in 20th Century Urban Design. Berlin: DOM Publishers, 2017.

Soto, Álvaro. 'Forma y Lugar'. Arquitectura 271-272 (1988): 134-49.

Tarquini, Aldo, ed. La Città Di Mario Ridolfi: Architettura, Urbanistica, Storia, Arte, Cinema, Fotografia. Roma: De Luca Editori d'Arte, 2005. La Forma Della Città Industriale. Terni. Il Progetto Delle Parti. Roma: De 
Luca Editori d'Arte, 2015.

Terni, Città d'autore: Guida Ad Un Percorso Ridolfiano. Terni: Comune di Terni, 1996. 
Figure 1. Graphic interpretation of three plans for Terni: 1885, 1886 and 1931. Elaborated by the authors.

Figure 2. Graphic interpretation of three different solutions for Corso del Popolo's area: entries for the Piano Regolatore's competition in 1932-33 and the Piano di Ricostruzione 1944-49. Elaborated by the authors.

Figure 3. Comparison between the damaged area by bombs, the demolitions planned by the Piano Regolatore 1937 and the Piano Regolatore Generale 1968. Elaborated by the authors.

Figure 4. Graphic interpretation of the sequence of plans produced for Corso del Popolo from 1933 to 1959 by Mario Ridolfi. Elaborated by the authors.

Figure 5. Graphic interpretation of the Variante al Piano di Ricostruzione. Piano Particolareggiato per l'area di Corso del Popolo. In red, the new buildings. In grey, the buildings to be demolished. The project for the Palazzo per Uffici Comunale has been added to this drawing. Elaborated by the authors.

Figure 6. General view of Franconi Apartment blocks in Corso del Popolo (ca. 1959). Unpublished drawing archived in the office of Eng. Giuseppe Belli, Terni. 100x75cm. Courtesy of Eng. Giuseppe Belli.

Figure 7. Collage of the Piani Particolareggiati designed by Mario Ridolfi and Wolfgang Frankl since 1956. Elaborated by the authors. 
Andreani, Francesco. 'Le Case Franconi in Corso Del Popolo'. In Mario Ridolfi Architetto 1904-2004, edited by Renato Nicolini, 176-86. Milano: Electa, 2005.

Andriani, Carmen. 'Palazzine Romane Di Mario Ridolfi: Dalla Rea Alla Zaccardi, Alterazione Distorsione e Corruzione Della Figura Razionalista'. Rassegna Di Architettura e Urbanistica 89-90 (1996): 122-29.

Aristotle, Kallis. The Third Rome, 1922-1943. The Making of the Fascist Capital. New York: Palgrave McMillan, 2014.

Bacon, Edmund N. Design of Cities. London: Thames and Hudson, 1978.

Bazzani, Cesare, Michele Giorgini, and Valter Tocchi. Cesare Bazzani: Un Accademico d'Italia. Perugia: Electa/Umbri Associati, 1988.

Bellini, Federico. Mario Ridolfi. Roma: Laterza, 1993.

Blundell, Peter. Gunnar Asplund. New York: Phaidon, 2006.

Bonaccorso, Giuseppe. 'Mario Ridolfi e La Cultura Tedesca: Frequentazioni, Influenze e Progetti Tra Il 1933 e Il 1938'. In Mario Ridolfi Architetto 1904-2004, edited by Renato Nicolini, 107-14. Milano: Electa, 2005.

Boyd Whyte, Iain. Modernism and the Spirit of the City. London: Routledge, 2003.

Brunetti, F. Mario Ridolfi. Firenze: Alinea, 1985.

Canella, Guido. 'Maestri Razionalisti e Neorealisti Italiani Nell'era Dei Graffiti?' Hinterland 13-14 (1980): 2-3.

Cavallari, Luigi. Ridolfi e Frankl: Progettare e Costruire. Il Nuovo Palazzo per Uffici Comunali a Terni. Pescara: Sala Editori, 2000.

Cellini, Francesco. 'Su Mario Ridolfi. Geometria e Costruzione Della Pianta Centrale'. Lotus International 37 (1983).

Cellini, Francesco, and Claudio D'Amato. Le Architetture Di Ridolfi e Frankl. Milano: Electa, 2005.

—. Mario Ridolfi All'Accademia Di San Luca: Edizione Critica Del Corpus Dei Disegni Di Architettura e Dei Documenti Dello Studio Ridolfi e Fondo RidolfiFrankl Malagricci (1924-1984) Dell'Archivio Dell'Accademia Nazionale Di San Luca. Roma : Graffiti, 2003. 
Cellini, Francesco, Claudio D'Amato, and Valerio Palmieri. Mario Ridolfi: Manuale Delle Tecniche Tradizionali Del Costruire: Il Ciclo Delle Marmore. Milano : Electa, 1997.

Clua, Álvaro. 'La Arquitectura Del Swing. Sutilezas y Perturbaciones de La Forma Urbana'. Palimpsesto 9 (2014): 6-7.

Comune di Terni. 'Relazione Summaria Sui Danni Arrecati Alla Città Di Terni Da Azioni Di Guerra e Provvedimenti Adottati e Da Adottare per i Lavori Di Riparazione'. Terni, 1945.

Coppa, Mario. 'Il Piano Regolatore Di Terni: Parte Seconda'. Urbanistica 35 (1962): $59-72$.

—_. 'Il Piano Regolatore Di Terni'. Urbanistica 34 (1961): 69-76.

Corbusier, Le. Urbanisme. Paris: Crès, 1925.

Covino, Renato. 'Percezione Della Città e Piani Urbanistici'. In La Città Di Mario Ridolfi: Architettura, Urbanistica, Storia, Arte, Cinema, Fotografia, edited by Aldo Tarquini. Roma: De Luca Editori d'Arte, 2005.

Cristofori, Cecilia. Terni e Bilbao. Città Europee Dell'acciaio. Milano: Franco Angeli, 2014.

De Solà-Morales, Manuel. A Matter of Things. Rotterdam: Nai, 2008.

—. 'La Segunda Historia Del Proyecto Urbano'. Revista UR 5 (1987): 21-27.

Emanuele, Caniggia. 'Il Nuovo Piano Di Ricostruzione'. L'Umbria Democratica. 19 November 1949.

Ercolani, Giampaolo. 'Architettura Di Ridolfi a Terni'. Controspazio 3 (1974): 84-101.

Fantozzi Micali, Osanna. Piani Di Ricostruzione e Città Storiche: 1945-1955. Firenze: Alinea Editrice, 1998.

Feduchi, Pedro. 'Mario Ridolfi: El Dibujo y La Renuncia'. Arquitectura 290 (1992): $110-16$.

—_. 'Memoria y Lugar: Una Reflexión Sobre La Actuación de Mario Ridolfi y Wolfgang Frankl En Torno Al Palacio Spada de Terni’. Arquitectura 271-272 (1988): 124-33. 
Fraticelli, Vanna. 'Terni: Progetto e Città'. Controspazio 3 (1974): 74-83.

Fuselli, Eugenio. 'Il Concorso Nazionale per Il Piano Regolatore Di Terni'. Architettura, no. 2 (1934): 107-17.

González Cubero, Josefina. 'Endurance and Transformation in Le Corbusier's Redent'. Journal of Architecture and Urbanism 40, no. 2 (2016): 60-74. doi:10.3846/20297955.2016.1194604.

Hegemann, Werner, and Elbert Peets. The American Vitruvius: An Architects' Handbook of Civic Art. New York: Architectural Book, 1922.

Morelli, Comunardo. 'Opere Di Ricostruzione. Provvedimenti Contingibili Ed Urgenti. Richiesta Di Parere All'Architetto Ridolfi. Relazione Del Sindaco Alla Giunta Nella Seduta Del 24 Novembre 1944', 1944.

Moschini, Francesco, and Luciana Rattazzi, eds. Mario Ridolfi. La Poetica Del Dettaglio. Roma: Kappa, 1997.

Nicolini, Renato. Mario Ridolfi: Architetto : 1904-2004. Milano: Electa, 2005.

Pacini, Renato. 'La Sistemazione Del Centro Di Brescia Dell'architetto Marcello Piacentini'. Architettura, no. 12 (1932): 649-73.

Palmieri, Valerio. Mario Ridolfi. Guida All'architettura. Verona: Arsenale Editrice, 1997.

Pendlebury, John, Erdem Erten, and Peter J. Larkham, eds. Alternative Visions of PostWar Reconstruction. Creating the Modern Townscape. New York: Routledge, 2015.

Pirro, Danilo Sergio. Enrico Lattes: L'architetto Ritrovato. Roma: Gangemi Editore, 2013.

Pizza, Antonio. 'La Arquitectura, La Narración, Mario Ridolfi y Sus Huellas'. In Mario Ridolfi (1904-1984). La Arquitectura de Ridolfi y Frankl, edited by Ricardo Sánchez and Lucas Recuenco, 231-40. Madrid: Ministerio de Obras Públicas y Transportes, 1991.

Polin, G. 'Mario Ridolfi, Volfango Frankl, Domenico Malagricci. Nuovo Palazzo per Uffici Del Comune Di Terni’. Casabella 489 (1983).

Portelli, Alessandro. Biografia Di Una Città. Storia e Racconto: Terni 1830-1985. 
Torino: Giulio Einaudi, 1985.

Portoghesi, Paolo. 'Presenza Di Ridolfi'. Controspazio 1 (1974): 6-11.

—. 'Una Città d'autore'. In Terni Città d'autore: Guida Ad Un Percorso

Ridolfiano, edited by Aldo Tarquini. Terni: Comune di Terni, 1996.

Prosperetti, Francesco. 'La Apertura Del Corso Del Popolo En Terni: Un

"Sventramento" de Mario Ridolfi'. Arquitecturas Bis 21 (1978).

Ridolfi, Mario. 'Progettare per Una Città Di Media Grandezza'. Hinterland 13-14 (1980): $30-35$.

—_. 'Relazione. Piano Di Ricostruzione Della Città Di Terni'. Terni, 1945.

—. 'Relazione. Variante Al Piano Di Ricostruzione Corso Del Popolo. Piazza Del Popolo e Zone Adiacenti', 1957.

Rowe, Colin, and Fred Koetter. Collage City. Cambridge, Massachusetts: The MIT Press, 1978.

Ryan, Brent D. The Largest Art: A Measured Manifesto for a Plural Urbanism. Cambridge: The MIT Press, 2017.

Sánchez, Ricardo, and Lucas Recuenco, eds. Mario Ridolfi (1904-1984). La Arquitectura de Ridolfi y Frankl. Madrid: Ministerio de Obras Públicas y Transportes, 1991.

Sergison, Jonathan, and Stephen Bates. Papers 3. Luzern: Quart Architektur, 2015.

Sitte, Camillo. Der Städtebau Nach Seinen Künstlerischen Grundsätzen, 1889.

Sonne, Wolfgang. Urbanity and Density in 20th Century Urban Design. Berlin: DOM Publishers, 2017.

Soto, Álvaro. 'Forma y Lugar'. Arquitectura 271-272 (1988): 134-49.

Tarquini, Aldo, ed. La Città Di Mario Ridolfi: Architettura, Urbanistica, Storia, Arte, Cinema, Fotografia. Roma: De Luca Editori d'Arte, 2005. La Forma Della Città Industriale. Terni. Il Progetto Delle Parti. Roma: De 
Luca Editori d'Arte, 2015.

Terni, Città d'autore: Guida Ad Un Percorso Ridolfiano. Terni: Comune di Terni, 1996. 
Figure 1. Graphic interpretation of three plans for Terni: 1885, 1886 and 1931. Elaborated by the authors.

Figure 2. Graphic interpretation of three different solutions for Corso del Popolo's area: entries for the Piano Regolatore's competition in 1932-33 and the Piano di Ricostruzione 1944-49. Elaborated by the authors.

Figure 3. Comparison between the damaged area by bombs, the demolitions planned by the Piano Regolatore 1937 and the Piano Regolatore Generale 1968. Elaborated by the authors.

Figure 4. Graphic interpretation of the sequence of plans produced for Corso del Popolo from 1933 to 1959 by Mario Ridolfi. Elaborated by the authors.

Figure 5. Graphic interpretation of the Variante al Piano di Ricostruzione. Piano Particolareggiato per l'area di Corso del Popolo. In red, the new buildings. In grey, the buildings to be demolished. The project for the Palazzo per Uffici Comunale has been added to this drawing. Elaborated by the authors.

Figure 6. General view of Franconi Apartment blocks in Corso del Popolo (ca. 1959). Unpublished drawing archived in the office of Eng. Giuseppe Belli, Terni. 100x75cm. Courtesy of Eng. Giuseppe Belli.

Figure 7. Collage of the Piani Particolareggiati designed by Mario Ridolfi and Wolfgang Frankl since 1956. Elaborated by the authors. 

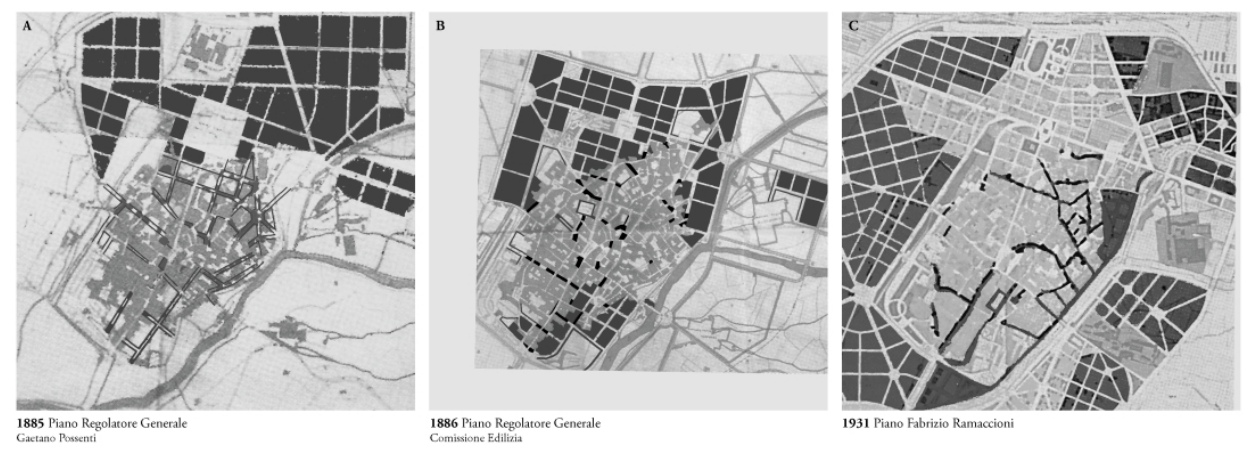

Figure 1. Graphic interpretation of three plans for Terni: 1885, 1886 and 1931. Elaborated by the authors. $420 \times 160 \mathrm{~mm}(300 \times 300$ DPI) 

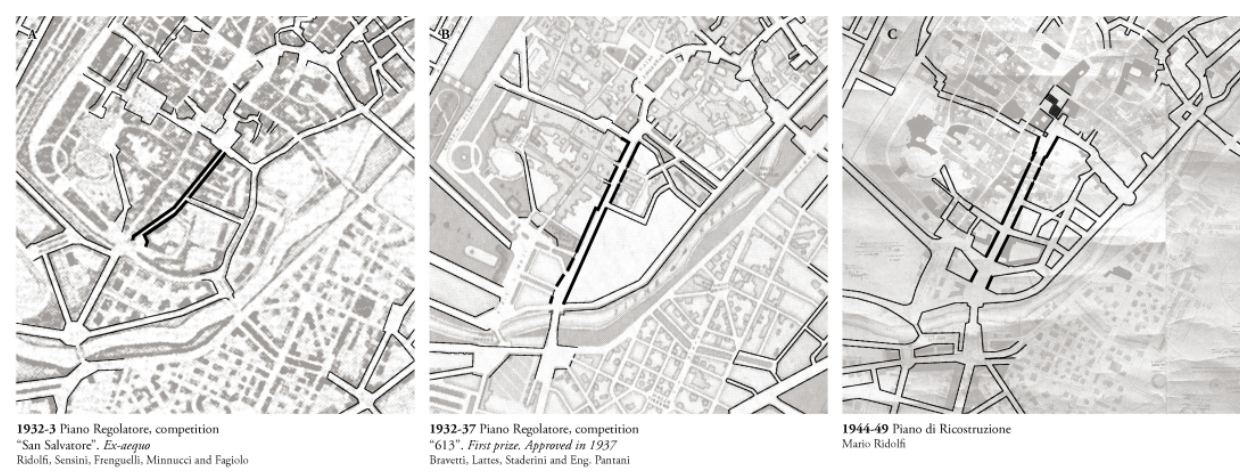

Figure 2. Graphic interpretation of three different solutions for Corso del Popolo's area: entries for the Piano Regolatore's competition in 1932-33 and the Piano di Ricostruzione 1944-49. Elaborated by the authors.

$420 \times 160 \mathrm{~mm}(300 \times 300$ DPI) 

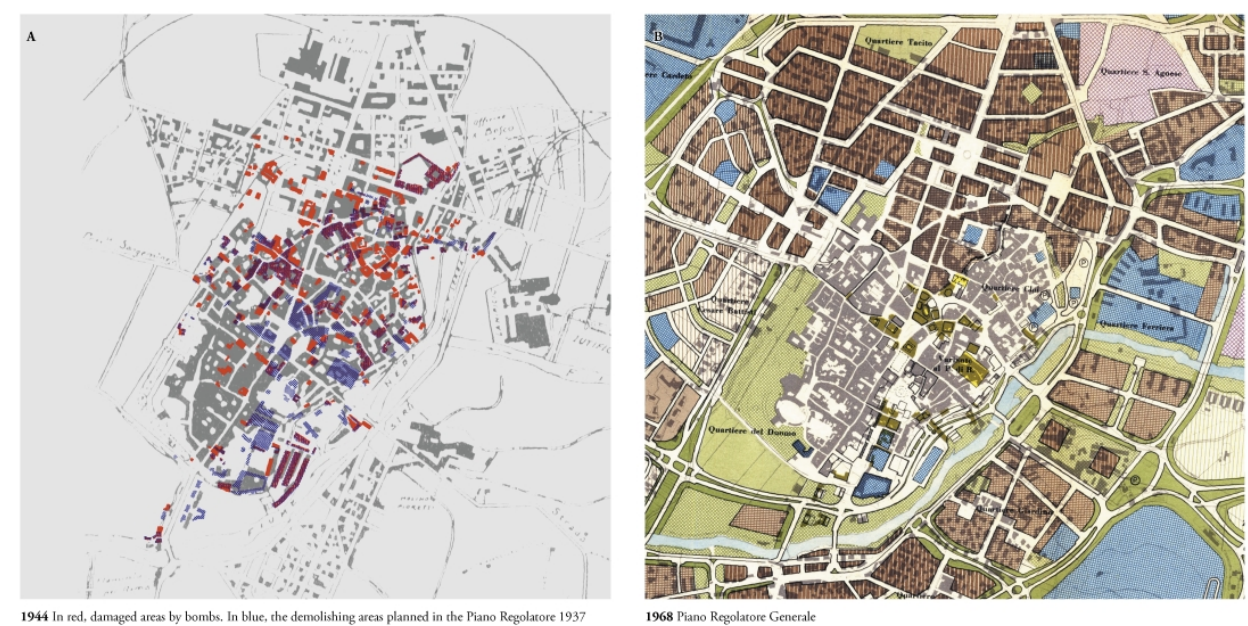

Figure 3. Comparison between the damaged area by bombs, the demolitions planned by the Piano Regolatore 1937 and the Piano Regolatore Generale 1968. Elaborated by the authors.

$420 \times 219 \mathrm{~mm}(300 \times 300 \mathrm{DPI})$ 
Figure 4. Graphic interpretation of the sequence of plans produced for Corso del Popolo from 1933 to 1959 by Mario Ridolfi. Elaborated by the authors.

$$
250 \times 739 \mathrm{~mm}(300 \times 300 \text { DPI) }
$$

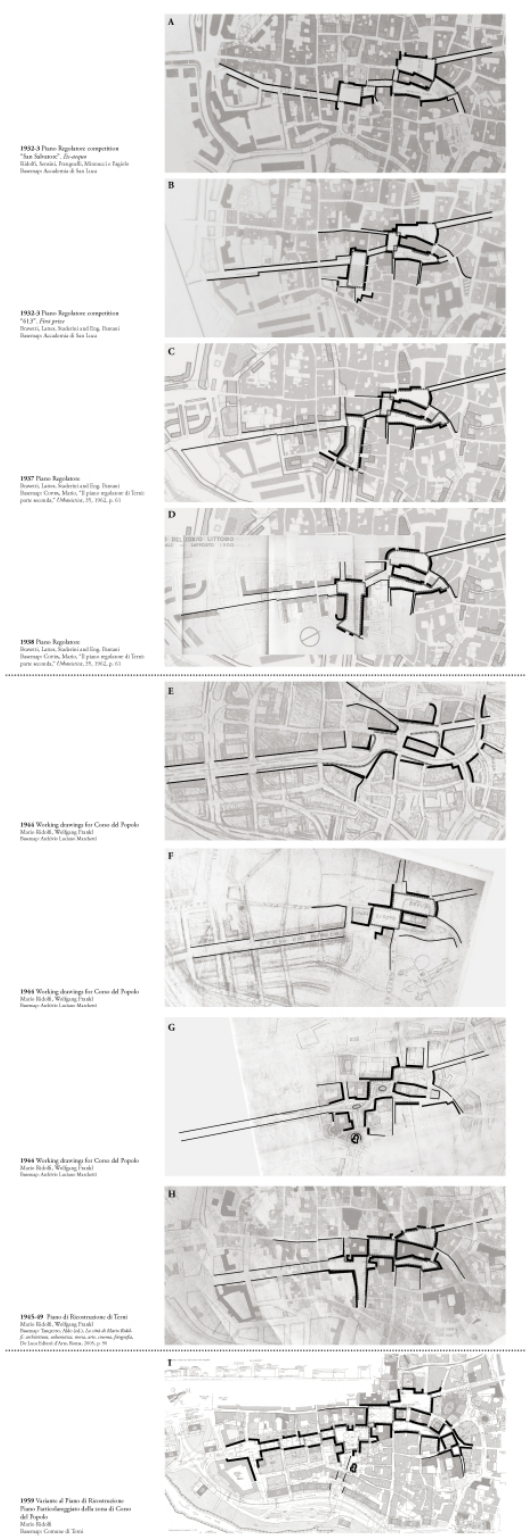


Figure 5. Graphic interpretation of the Variante al Piano di Ricostruzione. Piano Particolareggiato per I'area di Corso del Popolo. In red, the new buildings. In grey, the buildings to be demolished. The project for the Palazzo per Uffici Comunale has been added to this drawing. Elaborated by the authors.

$600 \times 459 \mathrm{~mm}(300 \times 300 \mathrm{DPI})$ 


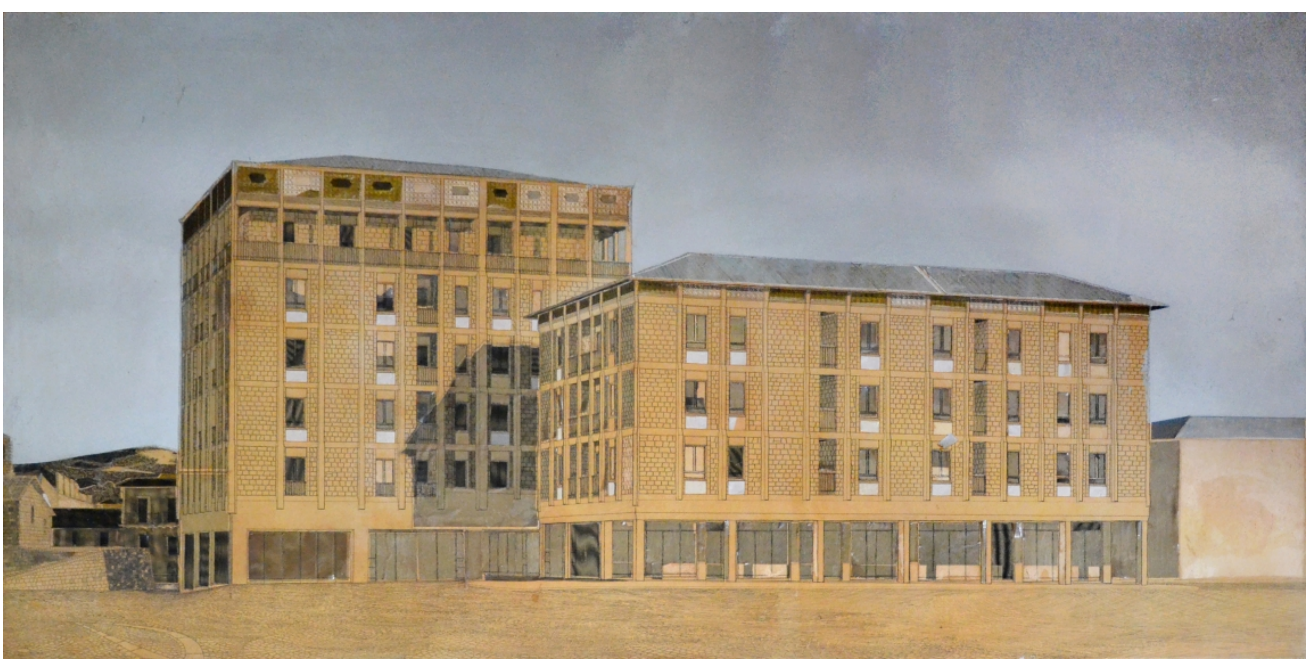

Figure 6. General view of Franconi Apartment blocks in Corso del Popolo (ca. 1959). Unpublished drawing archived in the office of Eng. Giuseppe Belli, Terni. $100 \times 75 \mathrm{~cm}$. Courtesy of Eng. Giuseppe Belli.

$289 \times 143 \mathrm{~mm}(300 \times 300 \mathrm{DPI})$ 


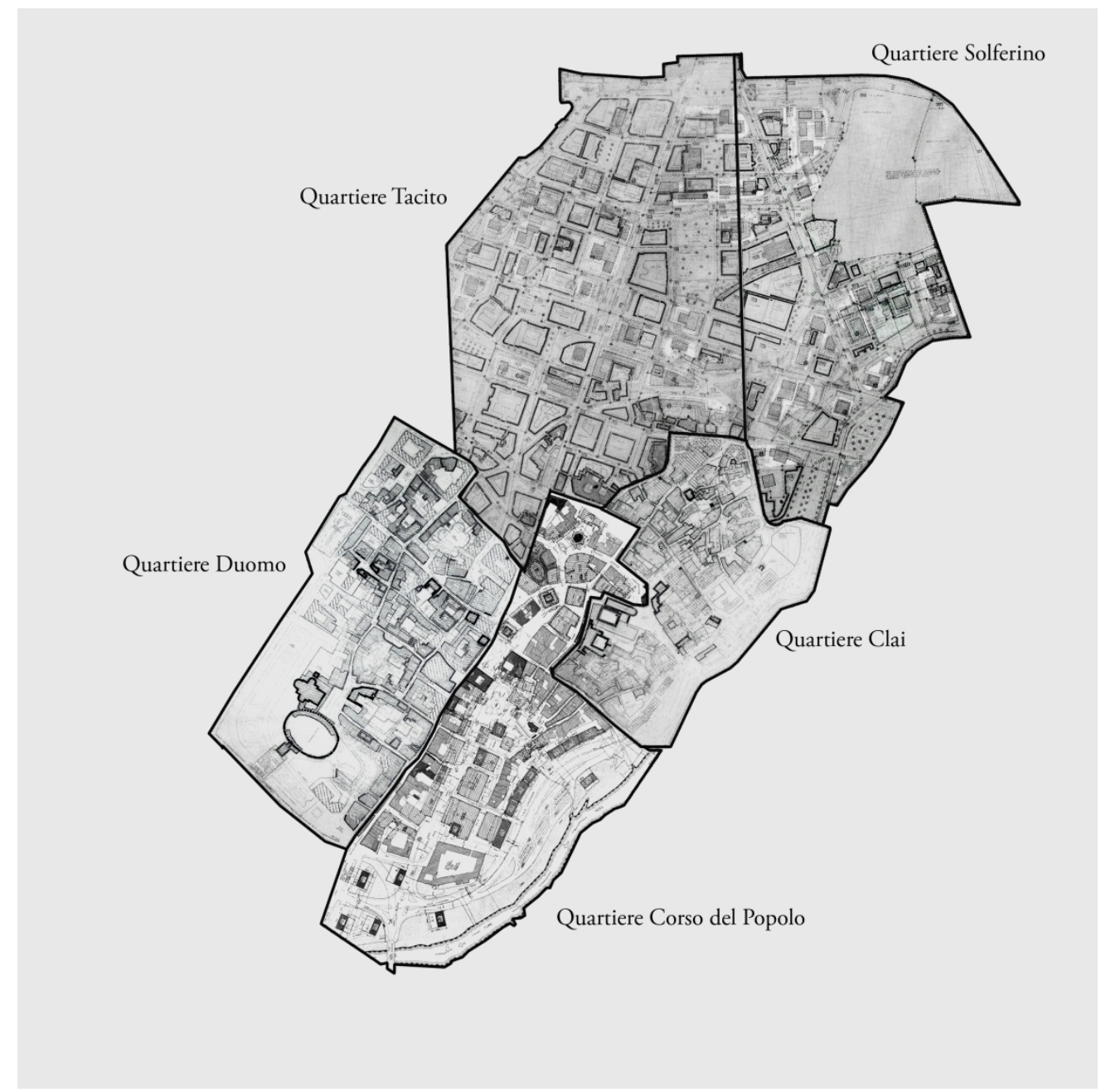

Figure 7. Collage of the Piani Particolareggiati designed by Mario Ridolfi and Wolfgang Frankl since 1956. Elaborated by the authors.

$228 \times 228 \mathrm{~mm}(300 \times 300$ DPI $)$ 